\title{
President's viewpoint/Mot du president
}

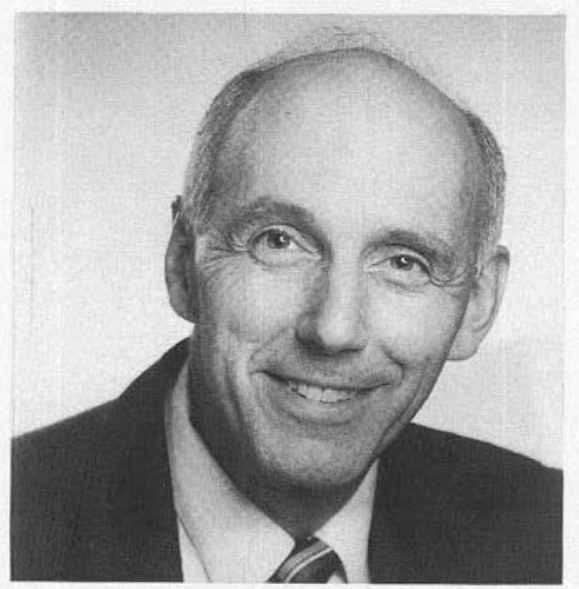

\section{A Canadian Code of Standards of Forestry Practice}

At the 1990 Annual Meeting of the Institute in Fredericton it was agreed to promote the development and adoption of a National Forest Practice Code. When the Canadian Federation of Professional Foresters Associations (C.F.P.F.A.) met during the same week, members agreed to cooperate in developing such a code. The recent report of the House of Commons Standing Committee on Forestry and Fisheries (the Bird Report) recommends the development of a similar code. The C.F.P.F.A. has not been able to move quickly to commence development of a code because the organization is informal and has no staff or office. The Institute has made some progress and intends to lead this innitiative.

Through our membership in the International Union of Societies of Foresters (I.U.S.F.) we have been able to obtain information on similar documents developed elsewhere in the world. The documents vary from codes of professional ethics to technical codes for forest practise on specific sites. The most interesting document we have received is the New Zealand Forest Code of Practice just completed in July 1990. This is a code developed by the New Zealand Logging Industry Research Association which provides a process to assist forest managers to develop site specific forest management prescriptions which balance environmental and commercial values. The New Zealand code may be too detailed an approach considering the wide range of conditions which exist in this country and may not adequately address the professional aspects which we will need to incorporate, but it is a very good document.

We hope that a Canadian code can be developed which will incorporate consideration of Sustainable Development and will be endorsed by all Professional Foresters Associations in the country as well as many responsible "environmental" groups. We envision a code which specifies how forestry decision making should be carried out rather than a technical site specific manual. Adoption of a National Code of Standards of Forest Practise will assist foresters to regain the confidence of the Canadian Public. Politicians want to see a code against which performance can be measured, and government will develop the code if foresters do not. There is no better qualified organization than the Canadian Institute

\section{Un code national d'excellence pour la pratique de la foresterie}

Lors de l'Assemblée annuelle de 1990 qui a eu lieu a Fredericton, il a été convenu de promouvoir l'élaboration et l'adoption d'un Code national d'excellence pour la pratique, de la foresterie. Au cours de la réunion de la Fédération canadienne des associations professionelles de forestiers (FCAPF) qui s'est tenue la même semaine, les membres ont accepté de coopérer a l'élaboration d'un tel code. Le récent rapport du Comité permanent des Forêts et des Pêcheries de la Chambre des Communes (le rapport Bird) recommande l'élaboration d'un code de cette nature. La FCAPF n'a pas été en mesure d'entreprendre rapidement l'élaboration du code puisqu'il s'agit d'une organisation informelle ne possédant ni personnel ni bureau. L'Institut a établi quelques jalons et entend prendre l'initiative dans ce dossier.

Grace, a notre adhésion a l'Union internationale des sociétés d'ingénieurs forestiers (I.U.S.F.), nous avons été en mesure d'obtenir de l'information sur des documents semblables rédigés un peu partout dans le monde. Les documents prennent la forme de codes d'éthique professionnelle ou encore de manuels techniques de pratique forestiere à suivre sur des sites spécifiques. Le plus intéressant document que nous avons reçu est constitué du Code d'excellence pour les forêts de Nouvelle-Zélande, tout juste complété en juillet 1990. Il s'agit d'un code élaboré par la New Zealand Logging Industry Research Association qui illustre la démarche à suivre pour aider les gestionnaires forestiers a mettre au point des prescriptions d'aménagement forestier spécifiques a un site donné et qui tiennent compte des données environnementales et commerciales. Le Code de la NouvelleZélande peut etre trop détaillé en tant qu'approche lorsqu'on considère la grande variété de conditions que existe au Canada et peut ne pas répondre adéquatement aux aspects professionnels que nous devrons incorporer, mais il s'agit d'un tres bon document.

Nous souhaitons qu'un code canadien puisse être élaboré et qu'il tienne compte de la question de Dévelopement durable et qu'il soit endossé par toutes les associations professionnelles de forestiers du pays ainsi que par autant de groupes "environnementaux" responsables. Nous envisageons un code qui spécifie comment le processus de prise de décision devrait être mené plutôt qu'un manuel technique spécifique à un site donné. L'adoption d'un Code national d'excellence pour la pratique de la foresterie aidera les forestiers à regagner la confiance du public canadien. Les politiciens veulent voir un code afin d'y référer pour évaluer une performance, et le gouvernement développera ce code si les forestiers ne le font pas. Il n'existe pas d'organisation mieux qualifiée que l'Institut Forestier du Canada/Canadian Institute of Forestry pour entreprendre cette tâche.

Même si le produit fini est très différent de ce qui est requis dans le code national, la Section Cariboo de l'Institut a élaboré deux codes de pratique forestière en préparation de la tenue des assemblées annuelles nationales de l'Institut. "A Forest Practice Code for the Spruce-Balsam Type"' a été complété en 1959 et "Recommended Forest Practices for the Central Interior of British Columbia" fut élaboré en 1969. 
of Forestry/Institut Forestier du Canada for spearheading this task.

Although the final product was quite different from what is required in a national code, the Cariboo Section of the Institute developed two forest practice codes in preparation for hosting national annual meetings of the Institute. "A Forest Practice Code for the Spruce-Balsam Type" was completed in 1959 and "Recommended Forest Practices for the Central Interior of British Columbia" was prepared in 1969. Looking at these documents today, it is obvious that technical codes have a very short useful life, but the real value of developing those codes was in the stimulating discussions which took place at section meetings when the committee presented their preliminary versions of the many sections of the code. There is an opportunity for sections all across the country to provide input into the development of a national code and this could best be done by having a local committee draft some preliminary ideas for presentation and discussion at a section meeting. The Executive Director at head office has summarized some of the information we have received so far and this could be made available to any interested section to get them started. Section executives will cooperate if members indicate an interest.

I hope that these comments arouse the interest of some members. I am sure that you would find great fun and value in discussing the contents of a forest practice code with other foresters at a section meeting. It is an opportunity to improve local communication and at the same time provide a valuable contribution to the development of an important national document.
L'étude actuelle de ces documents nous révele qu'il est évident que les codes techniques ont une très courte vie utile, mais que la vraie valeur de l'élaboration de ces codes réside dans les discussions stimulantes qui ont lieu lors des rencontres de section pour discuter des versions préliminaires des différents parties du code présentées par le groupe de travail. Il existe une possibilité pour les sections de tout le pays de participer à l'élaboration d'un code national et ceci pourrait être fait par un comité local qui proposerait quelques idées préliminaires dans le but de les présenter et d'en discuter, lors d'une rencontre de la section. Le directeur exécutif au siège social a constitué un sommaire d'une partie de l'information que nous avons reçue à ce jour et celle-ci pourrait être mise a la disposition de toute les section intéressée à aller de l'avant. L'exécutif des sections coopérera si les membres indiquent leur intérêt.

Je souhaite que ces commentaires soulèveront l'intérêt de quelques membres. Je suis certain que vous aurez plaisir et que vous trouverez de l'intérêt a discuter du contenu d'un code d'excellence pour la pratique de la foresterie avec d'autres forestiers lors d'une réunion de section. Ceci constitue une opportunité pour améliorer les communications locales et en même temps apporter une contribution valable à l'élaboration d'un important document national.

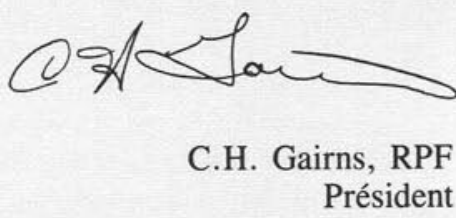

\section{United Nations to Hold "Earth Summit" in 1992}

A Committee of the General Assembly has decided that the United Nations Conference on Environment and Development (UNCED) will be an "Earth Summit". The Second Committee voted to invite Heads of State and Government to participate in the Conference, which is to be held in Rio de Janeiro, Brazil, from 1 to 12 June, 1992.

At the same time, the Committee decided that nongovernmental organizations (NGOs) with special relevance to the Conference would be able to participate in its preparations.

In calling for the Conference on Environment and Development, the General Assembly hoped to provide a forum for Governments to agree on integrated actions that will ensure the security of the planet. Participation at the highest level - of Prime Ministers and Presidents - is considered desirable so that Governments can make binding commitments to the decisions taken in Brazil.

"Nothing less than the fate of the world is at stake, Mr. Maurice Strong (Canada), Secretary-General of the Conference, has said. "Development is the process by which we affect the environment; environment is what is left after development".

The Conference represents a follow-up to the 1972 UN Conference on Environment, held in Stockholm, and the 1987 report of the UN World Commission on Environment and Development (the Brundtland report).

\section{New Editor-in-Chief Appointed for NRC Research Journals}

Dr. Bruce P. Dancik, Chair of the Department of Forest Science at the University of Alberta, has been appointed Editor-in-Chief of the National Research Council's thirteen Research Journals.

Dr. Dancik is the first Editor-in-Chief from outside NRC. He has been at the University of Alberta since 1973, teaching dendrology and forest genetics, and leading a research team in the population genetics of forest trees.

In 1978, he chaired hearings for the Environment Council of Alberta, and authored the resulting report on the Environmental Effects of Forestry Operations in Alberta. He was awarded the Canadian Forestry Achievement Award of the Canadian Institute of Forestry in 1979.

$\mathrm{He}$ recently chaired a panel reviewing proposed forestry developments in northern Alberta for the Ministry of Forestry, Lands and Wildlife and presented a final report in May of 1990 entitled Forest Management in Alberta.

Dr. Dancik has been Assistant Editor-in-Chief for the journals for the last three years. He has also been Editor of one of the NRC journals, the Canadian Journal of Forest Research, since 1980.

"My objective is to encourage our editors to maintain and promote their journals to be the flagships of their disciplines," says Dancik. "We will have to be diligent and innovative to ensure that the NRC Journals continue to serve the changing needs of the Canadian scientific community." 


\section{B.C. Forestry Agreement Announced}

A $\$ 200$ million forestry agreement between British Columbia and Canada was announced in mid-November. The deal was much less than the $\$ 700$ million some were hoping for and drew criticism from several groups. The B.C. government stated that it reluctantly agreed to the deal and was verbally promised additional funds through the federal government's soon to be released Green Plan. The B.C. government stated that silviculture jobs will be maintained, despite the lower level of agreement funding, and that claims that 100,000 jobs could be lost were "ridiculous" allegations.

\section{Forest Industry Financial Outlook Bleak}

The financial outlook in forest products continues to be poor. The strong Canadian dollar, high interest rates and the poor U.S. housing market are said to be the key factors producing this trend. However, it is generally felt that companies will be better able to weather this downturn since they already experienced deep cuts in the early 1980's and this time around, interest rates and inflation are not as high as they were at that time. Companies have taken steps like reducing long term debt, and the workforce has been reduced. There is a concern about the recovery from this trend since U.S. demand may not recover like it did in the mid-eighties, environmental costs continue to be a factor and there are concerns about logging methods, wilderness, old growth and other issues which may impact on the speed of recovery.

\section{Labrador Forest to be Developed}

The Newfoundland government is hoping to develop the forest of Labrador. Several problems will have to be addressed. The forest is described as mature and overmature, infrastructure such as roads and other services will be required and the cost of shipping products to markets will likely be very high. The government is optimistic that these difficulties can be addressed.

\section{Softwood Lumber Export Tax}

The U.S. is strongly committed to enforcing the Memorandum of Understanding which set up the 1986 agreement whereby Canada collects a 15 percent tax on softwood lumber exports to the U.S. The U.S. Commerce Secretary stated that they are firmly committed to take any action necessary and appropriate to enforce the terms of the agreement. Despite the current economic conditions Canadian lumber producers are experiencing, the Americans feel that they do not affect alleged subsidies. With the Canadian dollar about 16 percent higher than it was in 1986 and with lumber prices continuing to drop, it is estimated that 1000 board feet of lumber was worth about $\$ 275$. in 1986 and is now worth about $\$ 190$. Costs are further increased by the addition of the export tax. Meanwhile, Ontario Premier Bob Rae has written Prime Minister Brian Mulroney and proposed a review of the tax; by federal and provincial governments and industry.

\section{Forest Resources Commission Reviewing B.C. Forestry}

The progress of the Forest Resources Commission in B.C. was recently reported on. The Commission is looking at many aspects of forestry including corporate concentration, funding for forest management, the tenure system, value added and competition from foreign sources, such as the Soviet Union. A report from the Commission is expected soon.

\section{Al-Pac Pulp and Paper Mill Approved}

Alberta-Pacific Forest Industries $\$ 1.6$ billion Pulp \& Paper Mill was approved on December 20. The mill will produce 500,000 air dry tonnes of pulp per year using mainly poplar. 1300 jobs are expected from what is described as the cleanest Bleached Kraft Mill ever proposed in Canada. Fifty percent of the FMA is made up of areas not subject to timber harvesting and the company is responsible for all regeneration and integration with other uses.

\section{Agreement signed for Northern Ontario Indian Lands}

The federal and Ontario government have signed an interim agreement with Northern Ontario Indians. The agreement covers land-use permits, licenses for land, occupation and letters patent, applications for tourist establishments, mining leases, potential hydroelectric developments, forest management agreements, wild rice harvesting, trapping, commercial fishing and environmental consideration for projects. The agreement will ensure that the Indian band will be notified of any plans or activities in the area covering a major portion of Northern Ontario above the 50th parallel.

\section{Logging Controversy in Wood Buffalo National Park}

The federal government is contemplating the purchase of a lease currently held by Canfor in Wood Buffalo National Park. The lease allows logging in the park (the only national park where logging occurs). Cutting practices have been subject to media criticism and regeneration efforts in the area are said to be completely lacking. The area has been described as "Carmanah North". 


\section{The Problems and Solutions}

The problem in Canadian forests today are largely the result of poor management.

It is long overdue that we become professional in the practice of forestry. We have professionalism in our forestry schools but away from the academic scene we are not practicing what we preach. We should treat forestry like other applied science professions.

Our public and corporate leaders have to start seeing the long-term benefits of good forestry even if economic problems occur in the short run.

David Jefferson Sudbury, Ontario

The above letter was written to Executive Director C.A. Lee. Comments from readers would be welcome.

\section{January 1991}

Dear Mr. Place:

This letter is in response to the article entitled "Some Assumptions Underlying Canada's Foreign Aid in Forestry", by Kumar, Sharma and Bennett (Forestry Chronicle, August 1990) and the letter appearing in the October 1990 issue written by Jayanti Negi.

The issues raised in the article and letter are, as the title implies, "Assumptions"' and not reality. The following comments address the key "Assumptions".

With regard to visible minorities, CIDA has not "ignored them'. Visible minorities make up $6.3 \%$ of Canada's labour force. Within the Scientific and Professional category, visible minorities make up $5.1 \%$ of CIDA staff. Despite this favorable position CIDA continues to increase the level of representation of visible minorities by identifying qualified individuals and through staff awareness training programs. Limited staff turnover and the limited number of qualified individuals interested and available for employment are the principle constraints to greater representation.

There are a number of CIDA contractors and consultants who are also members of visible minority groups. No records, however, are kept on their level of representation. CIDA is increasingly trying to find the best qualified candidates as employees or consultants regardless of whether they belong to visible minority groups. The benefit from the expertise that visible minority groups can bring to the administration of the aid program is clearly recognized.
The section of the article which attempts to describe CIDA's development philosophy is misleading in its numerous misconceptions and broad generalizations. Our forestry sector program is clearly focussed towards addressing the needs of the poorest countries of the world and the need to confront the pressing global issues of weak economies, environmental degradation, climate change and diminishing biodiversity. The successes far outweigh the failures and our program continues to evolve.

For an accurate description of our forestry sector program the authors and other interested readers are encouraged to read "The Role of CIDA in International Forestry Development"' which was published in the June 1990 issue of The Forestry Chronicle.

The article attributes the general findings of the Winegard Committee Report (WCR 1987) directly to forestry sector policy and programs. The WCR was based on an extensive review of CIDA which covered the entire Agency. The report did not base its findings directly on CIDA forestry sector activities. The authors have failed to recognize the global framework within which the WCR was conducted. Similarly, they have chosen to omit, or failed to recognize, changes made in our forestry sector policy since the WCR was issued in 1987.

The paper states that 70 percent of all the goods and services on all bilateral projects must be procured in Canada. This is not true. CIDA's tied aid policy was revised in 1987. The current policy with regard to bilateral assistance is that for the most needy countries (in Africa south of the Sahara and for the least-developed countries in other regions) aid may be untied to a level of 50 percent. In all other countries $331 / 3 \%$ of our aid may be untied. Furthermore, all international humanitarian assistance is completely untied.

It is unfortunate that the article does not provide an accurate account of CIDA's forestry program. It is also surprising that The Forestry Chronicle, a responsible professional journal did not verify the articles content, with knowledgeable professionals in the public and private sector, prior to publishing it as fact.

The need to address tropical forestry conservation and development has never been more acute. As concerned citizens and knowledgeable professionals we must work together with our colleagues in developing countries and apply our collective strengths. To do otherwise will aid and abet the demise of the tropical forests.

Ralph W. Roberts, R.R.F., ing. f.

As populations worldwide begin to reflect on the testament they will be leaving to their successors, vigourous efforts surely will be forthcoming to ensure, while time remains, that this decade reverses the shameful elements of the preceding nine.

Ivan Head, President International Development Research Centre 


\section{Forestry Dialogue Forestier}

\section{INFORMATION FOR PARLIAMENTARIANS-INFORMATION POUR LES PARLEMENTAIRES}

\section{\# 34 DECEMBER 1990}

\section{RECYCLING}

Everyone favours recycling to reduce waste, and the practice of recycling paper has been common in many places in the world for several decades. However, recycling newspapers does have some adverse environmental impacts which limit its potential in Canada.

A number of cities and one U.S. state have legislated a minimum percentage of recycled fibre to be included in newspapers. A recent Toronto by-law will require 50 percent recycled fibre to be used in newspapers in street boxes by July 31,1991 . Although this is an admirable goal from the point of view of conservation of wood fibre, it may not be attainable without significant extra cost and spinoff adverse environmental impacts.

Canada uses only 12 percent of the 10 million tonnes of newsprint it produces annually with the rest exported to the U.S., continental Europe, Great Britain and about 40 other countries. This means that, even if we were able to achieve a 40 percent recovery rate on all of the newsprint used in Canada, and if all of the Deinking plants publicly announced came on stream as expected, by the end of 1992 we will have an annual short fall in the availability of old newspapers in the order of 600,000 tons. This will mean a significant increase in the volume of old newspapers imported into Canada. In 1989 we imported approximately 53,000 tonnes of old newspapers, all of which came from the U.S. The energy costs associated with bringing this increased volume of old newspapers back into Canada could be significant.

A second environmental problem associated with recycling newsprint is the creation of sludge. Deinking newsprint results in 90 percent useable fibre and 10 percent sludge, on a dry basis. The sludge is made up of coloured ink, carbon black and broken wood fibre. Some can be used as a soil conditioner, but the rest must be land filled.

The Canadian paper-making industry is responding to the rising demand for recycled products with new facilities coming on stream in Ontario, Quebec and probably soon in B.C. More made-inCanada recycled paper products will soon be available but we must understand that recycling of newsprint is not without adverse environmental impact. The environmental impact of harvesting trees for newsprint production is inherently a part of a much broader recycling process involving the release of carbon into the atmosphere by burning or decaying paper and the capturing of carbon by trees as forest stands are reestablished and grow to maturity. A proper balance of systems with the least overall adverse environmental impact will prove to be best for Canadians.

\section{\# 34 DÉCEMBRE 1990}

\section{RECYCLAGE}

Beaucoup de gens estiment que le recyclage permet de réduire les déchets et le recyclage du papier est chose courante dans plusieurs localités réparties dans le monde depuis plusieurs décennies. Toutefois, le recyclage du papier journal comporte quelques impacts environnementaux négatifs qui limitent son potentiel au Canada.

Plusieurs municipalités ainsi qu'un état américain ont légiféré qu'un pourcentage minimal de fibres recyclées devait être inclu dans le papier journal. Un récent règlement de la ville de Toronto exige que les journaux des boîtes distributrices devront contenir 50 pourcent de fibres recyclées d'ici le 31 juillet 1991. Même s'il s'agit d'un objectif louable du point de vue de la conservation de la matière ligneuse, il se peut qu'il ne soit pas atteint sans coûts supplémentaires significatifs et sans retombées d'impacts environnementaux négatifs.

Le Canada utilise seulement 12 pourcent des 10 millions de tonnes de papier journal qu'il produit annuellement, la balance étant exportée aux É.-U., vers l'Europe continentale, la Grande-Bretagne et 40 autres pays. Cela signifie que, même si nous étions capables d'atteindre un niveau de 40 pourcent de récupération de tout le papier journal utilisée au Canada, et même si toutes les usines de désencrage annoncées publiquement venaient à produire tel que prévu, nous aurions vers la fin de 1992, undéficit annuel dans la disponibilité de vieux journaux de l'ordre de 600000 tonnes. Cela signifie une augmentation importante du volume de vieux papier journaux importés au Canada. En 1989, nous avons importé approximativement 53000 tonnes de papiers journaux usagés, toutes en provenance des É.-U. Les coûts énergétiques associés au transport de ce volume accru de vieux papiers journaux au Canada pourraient être significatifs.

Un deuxième problème environnemental associé au recyclage de papier journal réside dans la production de boue. Le désencrage du papier journal permet la production de 90 pourcent de fibres utilisables mais produit aussi 10 pourcent de boue, sur une base de matière sèche. La boue est composée d'encre colorée, de noir de charbon et de fibres brisées de bois. Une partie de cette boue peut être utilisée comme amendement de sol, mais le reste doit être enfoui.

L'industrie canadienne de fabrication de papier répond à la demande croissante de produits recyclés par de nouvelles usines en construction en Ontario, au Québec et probablement bientôt en C.-B. Des quantités plus importantes de produits de papier recyclé fabriqués au Canada seront bientôt disponibles, mais nous devons comprendre que le recyclage de papier journal comporte des impacts environnementaux négatifs. L'impact environnemental de l'abattage des arbres pour la production de papier journal est une partie inhérente d'un processus de recyclage beaucoup plus grand qui comporte l'émission de carbone dans l'atmosphère par la combustion ou la dégradation du papier, et la fixation du carbone par les arbres dès que les peuplements forestiers sont régénérés et croissent jusqu'à maturité. Un équilibre adéquat des systèmes comprennant l'impact environnemental le plus réduit s'avérera être le meilleur pour tous les Canadiens. 


\section{Forestry Sub-committee Calls for a Strengthened Forestry Canada}

As reported briefly in Forestry Update in the December issue of The Forestry Chronicle, the report of the Subcommittee on Forestry of the House of Commons Standing Committee on Forestry and Fisheries was tabled in November 1990. The report blends together economic and environmental imperatives and notes that the challenge is to reconcile these two often conflicting imperatives. The main theme presented is that "If Canada is ever going to practice sustainable development successfully, it must begin in our forests." The all-party sub-committee, chaired by J.W. Bud Bird, has called for an expanded organizational mandate for Forestry Canada, one which would ensure consolidation of major federal activities relating to forest land management, forestry and forest industries within Forestry Canada and which would provide the financial and human resources necessary to fulfill the responsibilities. The philosophical foundation for the department would rest on the principles of sustainable development and stewardship and on cooperative and collaborative partnerships with the provinces, the territories and all other stakeholders.

The report recommends that Forestry Canada be given the following responsibilities:

(1) providing improved forest management and stewardship on federally owned forest lands including National Defence bases, Indian Reserve forests and Canadian parks,

(2) developing policies and procedures to ensure consistent application of the concept of sustainable forest development in the federal Environment Assessment Review Process (EARP),

(3) managing the Canadian Wildlife Service,

(4) managing the Canadian Parks Service,

(5) developing a national data base and inventory technology for all forest resources.

(6) managing the Forest Products Directorate currently in the Department of Industry, Science and Technology,

(7) increasing Canada's international forestry role, and

(8) expanding its research and development role in forest science and technology.

Furthermore, the report recommends that Forestry Canada be given the responsibility for federal-provincial forestry agreements and that these be developed for long-term periods, subject to revolving review and renewal at regular intervals. Forestry Canada should also take the lead in cooperation with the Canadian Council of Forest Ministers (CCFM) towards developing a national vision for sustainable forestry development which would be formally specified in a Canada Forests Accord. Still other recommendations call for Forestry Canada to develop, in co-operation with the Canadian Federation of Professional Foresters' Association, national standards for professional forestry practice, to conduct a substantial program of public communication, and to establish, with the provinces and the Canadian Federation of Woodlot Owners, a comprehensive and long-term program for woodlot management in Canada.

The sub-committee report is based on extensive hearings that were carried out between January and May 1990 and has been endorsed by a panel of forest educators, comprising G.L. Baskerville, University of New Brunswick, J.R. Carrow, University of Toronto, Claude Godbout, Laval
University, Kenneth Lertzman, Simon Fraser University and F.L.C. Reed, University of British Columbia. In their foreword they endorse the analyses and conclusions of the report. In particular, they stress that sustainable forestry development is the goal, but they note that sustainability does not imply the status quo, but rather enhanced values and volumes from the forests, and therefore a wider range of choices.

The strong support for a strengthened federal forestry role, and specifically for Forestry Canada, should be welcomed by the forestry community in Canada. The Institute has been echoing this refrain for many years and it is indeed encouraging that politicians from the three political parties are in agreement.

It should be noted that the Chairman, J.W. Bud Bird, Fredericton-York-Sunbury, is one of only six Honourary Members of the CIF/IFC. He was accorded this honour as a result of his leadership in developing a comprehensive forest policy for New Brunswick. It is encouraging to note that he is now providing national leadership in forestry and environment. Other Sub-committee members are Guy H. Arsenault, Restigouche-Chaleur, Réginald Bélair, CochraneSuperior, Brian L. Gardiner, Prince George-Bulkley Valley, Dave Worthy, Cariboo-Chilcotin, Darryl Gray, BonaventureIles-de-la-Madeleine, and Ken Monteith, Elgin-Norfolk.

\section{Forestry and Wildlife Groups Support Forestry Sub-committee Report}

Several forestry and wildlife groups have endorsed the report of the forestry sub-committee and participated collectively in a press conference in Ottawa on December 17, 1990. The press conference, convened by the Canadian Forestry Association, was attended by representatives of the Canadian Institute of Forestry/Institute forestier du Canada (CIF/IFC), Canadian Pulp and Paper Association (CPPA), Canadian Nature Federation, Wildlife Habitat Canada, Canadian Federation of Woodlot Owners, Canadian Wildlife Federation and Ducks Unlimited. A supporting statement was also provided by the Canadian Federation of Professional Foresters' Association (CFPFA).

In commenting on the report, Chris Lee, Executive Director, CIF/IFC, noted that the organization strongly supported the report and its recommendations. He specifically noted the report's focus on sustainable development, on the need for a code of practice for forest management, on national forest statistics and on federal influence on forestry practices. Evelynne Wrangler, President, CFPFA, stated that the report was given wide support by Canada's professional forestry community, while Wildlife Habitat Canada welcomed the "timely and forward looking document" and applauded the formal recognition of the need to manage the forest rather than the trees. The CPPA noted that a renewed federal commitment to the forest is important to all interests in the sector.

Three of the groups expressed reservation concerning the recommendations calling for the transfer of the Canadian Wildlife Service and the Canadian Parks Service to Forestry Canada. Ducks Unlimited suggested that a Department of Natural or Renewable Resources be established while the Canadian Wildlife Federation suggested that there be a federal department responsible for wildlife, freshwater fisheries, parks and forests. Similarly the Canadian Nature Federation strongly disagreed with the proposals for transfer of the two 
agencies. The organizational proposal was also denounced in a preses release issued the same day by a coalition of six environmental groups including Canada's Future Forest Alliance, The Canadian Environmental Network - Forest Caucus, Greenpeace, Friends of the Earth, Cultural Survival and the Green Coalition.

At the conclusion of the press conference, the two opposition environmental critics, Jim Fulton, NDP, and Paul Martin, Liberal, stated their opposition to the recommendations for transfer of wildlife and parks. The suggested that Environment Minister Robert deCotret was also opposed to the transfer, but Leo Clark, deCotret's parliamentary secretary, has said that it was inappropriate for the two critics to speak on the Minister's behalf. Fulton also stated that the NDP does not now endorse the report, even though it was signed by their forestry critic, Brian Gardiner, and subsequently approved by David Stupich, another NDP and a member of the Standing Committee. Fulton also expressed his disagreement with the suggestion that the timber harvest could possibly be doubled by the year 2050 .

\section{Bud Bird Comments on Forestry Report}

In an interview conducted on December 20, 1990, J.W. Bud Bird, discussed the report of the Forestry Subcommittee. He spoke on such topics as sustainable development, integrated forest management, a vision for Canada's forests and on federal-provincial relationships.

Mr. Bird noted that sustainable development in Canada must begin in the forests which "means that we must commence to address all of the values of all of the resources, and all at the same time". This is the pivotal issue in the report; society must establish long-term goals and decide what values are wanted from the forests. For example, how many jobs should there be? what kinds of timber are wanted? how much harvesting should there be? how much old-growth timber should be preserved? how much area should be in parks? It is evident that not all goals that are desired can be realized and trade-offs will be required in order that sustainable forestry is practiced. Mr. Bird noted that the report suggests a process for developing long-term goals - a vision for our forests. Each province and territory must develop its vision and these would be brought together through the Canadian Council of Forest Ministers (CCFM) and confirmed in a Canada Forests Accord. The CCFM would provide the structure, the accord would be the working document.

In commenting on the proposal to transfer the Parks and Wildlife Services to Forestry Canada, Mr. Bird stressed the need to integrate timber interests with other forest resources. "If timber was not contaminated with wildlife or recreational considerations, sustainable development will not occur. The risk is not in managing by integration; the risk is continuing to manage in isolation". The report invites environmentalists into the timber forest, but $\mathrm{Mr}$. Bird is concerned that they are not ready to accept the invitation. However, the MP now suggests that Forestry Canada be re-named "Forests, Parks and Wildlife" rather than Forests Canada as advocated in the report. However, he does not favour the title Renewable Resources, noting that in his opinion Forests should be included in the name of the department.

Mr. Bird expressed his concern with the junior status of forestry in the federal government and suggested "that it was time that forestry was taken seriously". He does not consider that provincial jurisdiction and authority presents a problem noting that there is a powerful federal role to be played in the forests of Canada. However he was quick to point out that such a role can only be played in partnership with the provinces. He indicated that all provincial governments are looking for federal investment in forest management through federal-provincial agreements and in forest research. They are, however, concerned about the overall capability of the federal government in forestry. Mr. Bird noted that six provincial governments had submitted briefs or had appeared before the Sub-committee.

Some critics of the report consider it to have an economic bias, particularly because of the suggestion that the timber harvest could be doubled by the year 2050. Mr. Bird noted, however, that the report also indicates that long-term goals for recreation and other non-timber values must provide for increased demand. Economic pressures will continue to increase and the key to providing additional non-timber values will be to increase timber production through enhanced forest management thus "freeing-up land for other uses".

The report includes a request that the government respond in accordance with Standing Order 109. This will require a formal reply from the Minister of Forestry within 150 days from the November 7 tabling of the report. There is a need for those who support the report to contact their MP and to communicate directly with the Offices of the Prime Minister and the Ministers of Forestry and Environment. Mr. Bird is calling for support and endorsement of his report and a stronger federal forestry role.

J.H. Cayford, R.P.F.

\section{Federal Government Releases Environmental Green Plan}

Canada's Green Plan was released by Environment Minister Robert R. deCotret on December 11, 1990. The Green Plant presents a co-ordinated package of actions to help Canadians work together in partnership to achieve, within a decade, a healthy environment and a sound, prosperous economy. Mr. deCotret announced that the plant is fully funded and commits the Government of Canada to $\$ 3$ billion in new funding for the environment. He indicated that the plan involves more than 40 federal departments and agencies and that it will be updated annually on the basis of emerging issues and priorities. The plan offers new policies, programs and standards to clean up, protect and enhance land, water and air, renewable resources, the Arctic, parks and wildlife and to reduce waste generation and energy use. Included also are measures to maintain global environmental security, foster environmentally responsible decision-making and improve Canada's emergency preparedness. More than 100 initiatives are set out. Funding allocations are very general and are outlined as follows:

Clean Air, Water and Land

Sustaining Renewable Resources

$\$ 850$ million

Special Spaces and Species

350

The Arctic

175

Global Environmental Security

100

Environmentally Responsible

Decision-Making

575

Legislation and Regulation

500

Federal Environmental Stewardship 
The release of the Green Plan culminates a process that has been in progress for more than a year. After several delays a discussion paper, A Framework for Discussion on the Environment, was issued in March 1990. This was followed by an extensive consultation phase from April through June, during which Environment Canada sponsored 41 information sessions and 17 two-day consultations. Finally a two-day summary consultation was held in Ottawa in August at which 400 delegates reviewed a 159-page document that summarized all of the previous sessions. In connection with the consultation, the Minister established a national advisory committee to provide advise. The CIF/IFC was the only forestry group represented on the committee. The committee maintained throughout the consultations that the discussion paper was an inadequate document for public consultation and that the final Green Plan should be a very definitive document outlining specific programs with detailed objectives and financing.

Given the 18-month gestation period and the extensive consultation, it is not surprising that the Green Plan has been widely criticized. In particular, environmental and public policy groups are concerned with the lack of detail and that new initiatives will require Treasury Board and cabinet approval. The document has also been criticized for its lack of program detail, lack of proposed new legislation and lack of financial detail. There is also concern that the proposal for a carbon tax has not been accepted by the government.

Representatives of the forestry sector will be pleased to learn of the inclusion of several forestry initiatives having the goal of shifting the management of Canada's forests from sustained yield to sustainable development. Specific initiatives include the creation of up to eight working models of sustainable development, better support for research and development of improved forestry products and processes, release of Canada's first report to Parliament on the state of Canada's forests, development and maintenance of a comprehensive national forestry data base covering such areas as forest harvesting and regeneration, establishment of a national forest seed and gene bank, the seeking of provincial co-operation for the identification and establishment of a national network of forest ecological reserves, the acceleration of computer-aided management tools and their transfer to forest managers, the tailoring of science programs to provide insight into such areas as climate change, biodiversity, acid rain and fire management and the launching of a community - participation program to plant 325 million trees over five years in rural areas, cities and towns nationwide to help absorb $\mathrm{CO}_{2}$.

In a supplementary document, Forestry Canada has described its involvement in the Green Plan under five programs - model forests, community tree planting, enhancing research, protecting biodiversity, and obtaining better information (See box). In reviewing these programs, the only rationale given for the community tree planting is to offset global warming. While the program may provide some benefits in this connection, one would hope that the program will also address other objectives such as improving wildlife habitat, reducing water erosion, improving ecological values and enhancing recreational opportunities.

It would appear as if Forestry Canada will be one of the big winners from the Green Plan. In addition to the five programs spelled out, the Department will also be involved in
Forestry Canada And The Green Plan

The federal government's Green Plan is designed to inform Canadians about the most serious environmental problems they face in the coming years and to describe some of the programs, laws and other actions the government will implement to address those problems. Forestry Canada played a major role in this initiative. Our involvement in the Green Plan is summarized below. Forestry Canada emphasizes the need for partnerships in delivering these programs.

\section{Model Forests}

- The government, in partnership with provinces and industry in the major Canadian forest regions, will encourage the creation of up to eight demonstration projects as working models of sustainable development. Forestry Canada will provide scientific support to its partners in the program, the land owners and the land managers.

\section{Community Tree Planting}

- In 1991, a community tree planting program will be launched as part of the action plan to offset Global Warming. Forests absorb $\mathrm{CO}_{2}$ from the atmosphere. The goal of this program is to encourage the planting of up to 325 million trees in rural areas and in and around the 6,000 cities, towns and communities across Canada. This program will encourage activities by individuals and organizations and will greatly accelerate the already significant momentum towards tree planting and reforestation in Canada.

\section{Enhancing Research}

Forestry Canada in response to the recommendations during public consultations will enhance forestry research to:

- develop more environmentally acceptable strategies for insect, disease and vegetation controls;

- better understand impacts of forestry practices on the natural forest ecosystem;

- better understand the interface between atmosphere and forests relative to climate change;

- develop more effective fire management strategies;

- better understand and offset forest declines;

- develop more environmentally acceptable manufacturing processes in the pulp and paper products industry.

\section{Protecting Biodiversity}

To protect against the loss of our genetic resources, Forestry Canada will:

- establish a national gene and seed bank;

- promote the establishment of forest ecological reserves.

\section{Obtaining better information}

There is a need to obtain information on the health of the forests and on man's interventions within the forest ecosystem. Forestry Canada with its partners will:

- expand the national forest database to include more information on the non-timber values;

- expand the ARNEWS (Acid Rain National Early Warning System) to become a monitoring system for the health of the forest. 
other Green Plan initiatives such as acid rain research, Fraser River basin studies and toxic chemicals research. Specific announcements concerning these programs can be expected in the near future, once Treasury Board and cabinet approval have been obtained. It is to be hoped that funding for forestry will amount to at least one-half of the $\$ 350$ million allocated for sustaining renewable resources.

The emphasis on forestry in the plan has been attributed, in part, to the strong and effective representation of the sector at both the information and consultation sessions. In addition, Minister Oberle played an important role during this period and helped ensure that forestry was front and centre in the plan.

\section{J.H. Cayford, R.P.F.}

\section{Organizational Changes for Forestry Canada}

Deputy Minister Jean-Claude Mercier has announced the following organizational changes for Forestry Canada.

Dr. Jag Maini has assumed the newly created position of Assistant Deputy Minister, Forestry Environment. Dr. Maini will act as advisor to the Deputy Minister on Canadian and International initiatives in the field of forestry environment. He will lead Forestry Canada's contribution to international conventions being drafted on Climate Change, Biodiversity and Forestry.

Tom Lee has become ADM, Forestry Policy, for one-year, while Dr. Yvan Hardy has become Acting ADM, Operations, for a period of six months. Normand Lafreniere has been named Acting Regional Director, Quebec Region for six months. The three appointments were effective December 1, 1990.

\section{Ontario Forest Industry Calls for Independent Auditors}

The Ontario Forest Industries Association (OFIA) has recommended that the Ontario Ministry of Natural Resources (OMNR) initiate an independent, external performance audit of the province's forests. Qualified audit teams would be appointed to assess timber management performance against plant objectives, and provincial regulations and guidelines. OFIA chairman Ted Boswell has said that "the audit can truly reflect the interests of the people of Ontario, the owners of the public forest."

Each active Crown Management Unit, where the OMNR reforests, and Forest Management Agreement, covering forest lands the forest industry is responsible for, would be audited every five years. The audit teams would report their findings to the Ontario legislature.

This information would benefit the preparation of subsequent five-year plans and simplify the management process.

Provincial annual reports, with summaries of Ontario's land and forest base and forest products industry statistics and volumes, would be published. And each Crown Management Unit and Forest Management Agreement would have its own annual report, which would include:

- a summary of management activities

- areas declared Free-to-Grow

- stocking results

- government revenues from stumpage and area charges
- expenditures on timber management

- and an estimate of the change in forest growth during the year.

The OFIA also called for greater public participation in plans for forest use, through the establishment of a tri-level committee structure representing the provincial government, all resource users and community groups. "People have a right to know what's happening in their forests. And they have a right to get involved in determining the priorities of that land," said Mr. Boswell.

\section{Forest Research Centre Opened in Sault Ste. Marie}

The new Ontario Forest Research Centre in Sault Ste. Marie was officially opened by Natural Resources Minister Bud Wildman on December 14, 1990. Construction of the $\$ 20.4$ million facility followed a decision by the Government of Ontario in 1987 to undertake a major decentralization program.

While providing important economic benefits for the Northern Ontario community, the relocation has provided an opportunity to expand the facilities with state of the art automated greenhouses, environmental growth chambers, laboratories and offices. The new centre is one of North America's most advanced forestry research complexes. Researchers will also profit from their proximity to the adjacent federal forest research facilities.

Forest research has been going on in Ontario since the 1900 s. In 1927 , a forestry board was formed to carry out "research in connection with the forest land of the province". In 1945, the then Department of Lands and Forests established a fully operational research station comprising fisheries, wildlife and forestry in Maple, north of Toronto. In 1981 the forestry section became the Ontario Tree Improvement and Forest Biomass Institute. The institute was renamed the Ontario Forest Research Institute (OFRI) in 1989. The Ministry of Natural Resources (MNR) established the institute to provide leadership in forest research and in the transfer of the research results to forestry practice. The institute's fields of research encompass many specialties and are recognized world-wide for their innovative research.

Work in progress at the institute covers forest genetics, tree breeding, biotechnology, soil science, forest ecology, stand management, tree physiology, and stock production. Projects include:

- breeding faster-growing, hardier, more disease-resistant trees with superior wood characteristics;

- improve stock handling and planting techniques to maximize survival and growth;

- promoting the regeneration of aging of cutover stands and ensuring continued productivity after harvest of highquality stands;

- distributing up-to-date information about all areas of the forest research to professional managers in the forest industries and in MNR.

Meanwhile, plans for developing a private, non-profit research corporation which would involve government, industry and universities appear to be on hold. The proposal originated with the Ontario Forestry Council, an advisory body which reports directly to the minister. 


\section{Nackawic, New Brunswick; Forestry Capital of Canada for 1991}

Nackawic, New Brunswick, the 1991 Forestry Capital of Canada has developed plans to make the event a year-round celebration. Activities have been scheduled for each of the 12 months and are listed in the Calendar of Events. The Forestry Capital of Canada is selected annually by the Canadian Forestry Association.

\section{Nackawic, New Brunswick: Forestry Capital of Canada for 1991}

\section{Calendar of Events}

April

Student Awareness Month

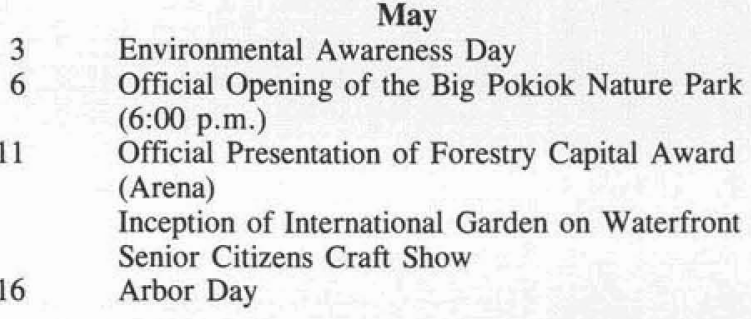

June

$15-$ Snowbirds

15 Black Powder Musket Shoot

15 Golf Tournament

15 Provincial Town Criers Competition

21-23 Maliseet Nation Cultural Exhibition

Pulp Mill Tours To Be Held throughout

July and August, 1991

\section{July}

1 Canada Day - Family Day Celebrations

6 Nackawic Annual Canoe Paddle

13 International Lumbermen's Competition

13 Firemen's Competition and Muster

20 Mayors Day

August

17 Raspberry Bluegrass Festival

17-18 Bass Tournament

24 Provincial Canoe and Kayak Races

30 Nackawic Community days/Corporate Challenge Photo Competition

\section{September}

Provincial Woodlot Owners Field Day

Joint Field Trip for Forestry Groups

\section{October}

Annual Meeting of Towns Association

Theme: "Forestry \& Environment"

November

Oldtimers/Celebrity Hockey Game Woodsmen's Ball

December

Closing Ceremony for Forestry Capital Celebrations

\section{CFA Undertakes Private Woodlot Taxation Study}

The current system of taxation for private woodlot owners does not serve as an incentive to woodlot management; indeed in many cases it serves as a disincentive.

This is the basic premise for a study of private woodlot taxation regulations to be undertaken by the Canadian Forestry Association. Consultant David Curtis has been hired to review existing policies and make recommendations which will allow all levels of taxation to serve as incentives to sound forest management.

Under a grant from Forestry Canada to CFA, Mr. Curtis began his study in December 1990 . Initially the study will focus on existing policies at all three levels of government: federal, provincial and municipal.

The study will determine the taxation regulations that affect private woodlot management and what steps are needed to a) encourage a well-managed forest resource in the long term and b) maximize the practice of woodlot management.

The study will be conducted in close consultation with key groups and individuals across Canada, including the Canadian Federation of Woodlot Owners. An initial step will be meeting with Dr. Jean-Paul Nadeau of the Quebec Department of Energy and Resources, who has prepared a report on woodlot taxation for the Quebec government.

Essentially, the project is an exercise in law reform, recognizing the 450,000 woodlot owners in Canada as a distinct entity. In terms of federal taxation policy, it is estimated that only about twenty per cent of woodlot owners are farmers, yet the income tax act views woodlot owners as farmers who gain supplementary income from their woodlots.

An approach is favoured whereby a system of taxation specifically designed for forest management and woodlots would recognize the wide variety of legitimate forest management objectives, and serve to assist owners in achieving these objectives.

Phase 1 of the study, a working draft, is expected to be completed by March 31 . Following this, a wide consultation process will be undertaken, with final recommendations ready by late summer 1991 .

\section{Fifty Years of Data on One CD}

Forestry CD-ROM, now being developed by $\mathrm{CAB}$ International, is a single compact disc that will contain over half a century of forestry information. Included will be all of the bibliographic citations and abstracts published in Forestry Abstracts (1939-1990), along with all of Forest Products Abstracts and Agroforestry Abstracts from their respective beginnings in 1978 and 1988 . Optical character recognition is being used to put the early information (1932-1972) into digitized format. This will be combined with the more recent records, which are already in computerized format, to produce a single database of forestry information. The disc is expected to be available in early 1992 . For more information, contact Deb Wiley, Marketing Manager for Electronic Publications, $\mathrm{CAB}$ International, Wallingford, OX10 8DE, UK; telephone: 0491/32111; telex; 847964 COMAGG G; fax: 0491/33508. 


\section{SILVILOG 1990}

Nova Scotia recently had the honour of hosting the third biennial Silvilog Forest Technology Show, held in Canada. In 1986 Petawawa, Ontario hosted the first Silvilog Exhibition ever held in Canada. In 1988, St-Georges-de Beauce, Quebec hosted the second Silvilog Show. With the great success of the two preceeding shows, a 1990 host was chosen. The new host was the Maritime Region, more specifically Parrsboro, Nova Scotia. Silvilog ' 90 was held on a 450 acre site in the Chignecto Management area, near Parrsboro, Nova Scotia on September 13th to 16th.

Silvilog was sponsored by Forestry Canada - Maritimes Region in cooperation with the Nova Scotia Department of Lands and Forests, the New Brunswick Department of Natural Resources and Energy, and the Prince Edward Island Department of Energy and Forestry.

The Silvilog Show, with its internationally flavored forum had something for everyone, whether you were a large company representative, a woodlot owner or just an interested citizen. The show featured many varied demonstrations of forestry equipment, from homemade power trailers to state of the art harvesting machines. The Show also hosted Water Bombing Displays, a Sugar Maple Display, an Interpretive Trail, Oxen and Horse Logging, a Pre-Commericial Thinning Competition, a Lumberjack Competition, a Slide/Tape Show, and Historical Display, the New Brunswick Woodmen's Museum, Homemade equipment, and even a band for entertainment. Several food take-outs were also located on the site.

Forestry Notes Nova Scotia Forestry Association

\section{A ABEEX \\ Aid FORESTRY CONSULTANTS \\ TEMPERATE AND TROPICAL FORESTRY FOREST INVENTORY DESIGN AND APPLICATIONS FOREST MANAGEMENT PLANNING AND OPERATIONS FORESTRY PROGRAMMES FOR MICROCOMPUTERS \\ P.O. Box 550 3439 McBean Street Richmond, Ontario KOA $2 Z 0$ \\ Phone: \\ (613) 838-2047 \\ 613) $838-5419$ \\ (514) 282-0686 1110 Sherbrooke $W$. Ste. 2304 \\ Montréal, H3A $1 \mathrm{G} 8$}

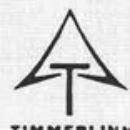

\section{TIMMERLINN LIMTrEe}

PROFESSIONAL AND TECHNICAL SERVICES IN FORESTRY AND ENVIRONMENTAL SCIENCES

R.R. No. 2, STE. AGATHE DES MONTS, QUE. J8C $2 Z 8$

\section{Canadian Forestry Accreditation Board} Bureau Canadien d'agrément en foresterie Accreditation Decision

University of Toronto, Faculty of Forestry, General Baccalaureate Program.

Accredited for six years to June 30, 1996.

\section{Comments}

Following consideration of the formal report of the site visit team submitted to the Canadian Forestry Accreditation Board in June 1990 , and related documentation, the Board granted unconditional accreditation of the General Baccalaureate Forestry Program, Faculty of Forestry, University of Toronto, for a period of six years to June 30 , 1996.

In its determination, the Board noted that a new curriculum has been introduced which will be fully implemented during the 1992/93 academic year. The Board will undertake a review of the program following the completion of the 1992/93 academic year.

The review will be carried out to ensure that the requirements of Board continue to be met as the new curriculum is introduced. The Board further noted that in accordance with the provisions of the policy statement, "the term of the accreditation is subject to review for cause at any time".

L.F. Riley, Chairman

J.H. Cayford, Director December 1990

\section{EDWARD S. FELLOWS MEMBER Canadian Institute of Forestry Forest Products Research Society etc}

FORESTRY \& FOREST PRODUCTS CONSULTANT

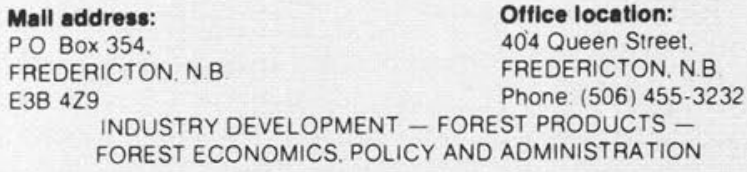

Woodlot Service (1978) Ltd.

"All Matters Pertalning to Forestry"

GORDON B. YOUNG, B.Sc.F., M.F.

Registered Professional Forester 